\title{
ポリゴン表現に基づく $\mathrm{CAM}^{*}$
}

\author{
乾 正知**
}

CAM Technology Based on Polygon Representation/Masatomo INUI

Key words: polygon representation, CAM, hardware acceleration, inverse offset method, milling simulation

\section{1.はじめに}

3 次元コンピュータグラフィックス $(\mathrm{CG})$ と切削加工 用 CAM. この二つの技術には大きな類似点がある. 3 次 元 CGでの主要な計算は, ある視点から眺めた立体形状の 画像を得ることであり，これは視点から伸びる直線（視 線）と立体の，一番手前の交点を得る問題に帰着する. 一 方, 3 軸切削加工の CAM における主要な計算は, $z$ 軸と 平行な姿勢の工具と金型などの製品形状の接触点を得るこ とだが，これは後述する逆オフセット法を用いると, やは り直線と立体形状の最も手前の交点を計算する問題にな る.

この類似性に着目して, CAM の問題解決に CG 技術を 利用する研究は, これまでにも参考文献 1 など幾つか知ら れているが, CAM の主要な技術にはなっていなかった.CG では描画対象をポリゴン形状に限定することが一般的だ が, CAM では複雑な自由曲面の扱いが不可欠であるこ と, $\mathrm{CG}$ 技術に基づくアルゴリズムを採用しても, CAM 計算の性能向上には必ずしもつながらないこと, などがそ の理由であった.

この状況は近年大きく変わりはじめている. CPUの高 速化とメモリーの大容量化に伴い, 自由曲面形状を精密に 多面体近似しても, 生成される膨大な数のポリゴンの処理 は, それほど大きな負担ではなくなってきた. 市販されて いるほとんどのパーソナルコンピュータ（PC）には, 1 秒間に数千万枚ものポリゴンを描画できる高性能なハード ウェアが搭載されている. CAM の問題を類似の 3 次元 $\mathrm{CG}$ の計算に置き換え，これをハードウェアで処理すれば，問

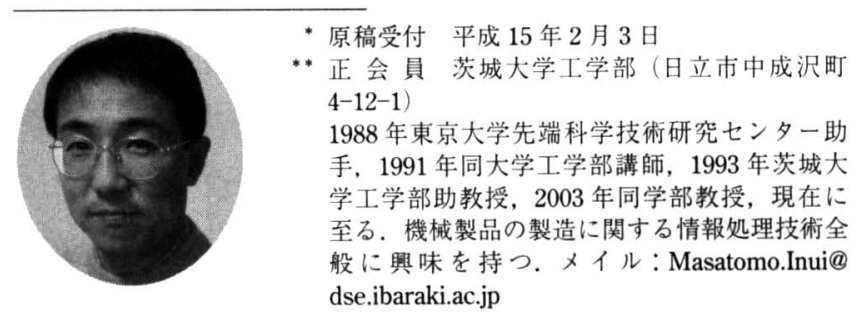

題解決に要する時間を大幅に短縮することが可能である.

これらの理由から，わが国の主要な CAM ベンダーと幾 つかの大手メーカは, 製品形状のポリゴン表現とグラ フィックス・ハードウェアを利用した, 超高速な CAM プ ログラムの開発に着手しており，すでに製品も登場してい る. 本稿では, この CG 技術に基づく新しい CAM の処理 手法について，われわれの研究グループの成果を中心に解 説する. ポリゴン表現に関するさまざまな技術は，本特集 の他の記事で十分に説明されているので，ここではグラフ イックス・ハードウェアの利用法を中心に述べることにす る.

\section{2. 基本的な考え方}

$\mathrm{PC}$ の筐体を開けてみると, グラフィックス表示用の小 さなカードが組み込まれていることがわかる．このカード には, 多面体の描画処理を高速化するための専用 LSI が搭 載されている.これはGPU (Graphics Processing Unit) と呼ばれ，ポリゴンをディスプレイへ表示する際に必要 な, 座標変換, 投影, クリッピング, 照明計算, 隠面消去 処理などを高速に実行する機能を備えている，GPUは性 能向上のペースが速く, ほほ半年に 2 倍のペースで高速化 されている.この種の LSI は家庭用ゲーム機でも使われる ため大量生産が可能であり, 結果的に高性能な GPUがご く安価に供給される状況になっている.

GPU は, 通常はポリゴン描画の高速化に使われるだけ だが, CAM と 3 次元 CG の類似性に基づいて, CAM の問 題を等価な CGの計算に置き換え, GPUの力を借りて処 理することで, 工具経路の算出や加工シミュレーションな どの複雑な計算の結果を, ごく短時間に得ることができる (図 1 参照).この手法では, 処理対象の製品形状などを 精密に多面体表現する必要がある。また処理結果はディス プレイ（正しくはフレームバッファ）へ画像として出力さ れるので, それをキャプチャーし, 画像から必要な解を抽 出する手間も増える. しかし主要な処理が GPUにより高 速化されるため, 多くの場合, トータルの計算時間を数十 分の 1 程度に短縮できる. 


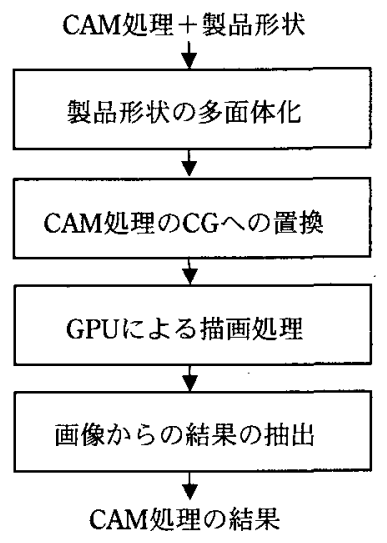

目 13 次元 $\mathrm{CG}$ 技術を利用した高速な $\mathrm{CAM}$ 処理

処理をハードウェアで行う場合に問題となるのは，ハー ドウェアの管理するデータにアクセスするためのドライバ や，LSI の機能をアプリケーション・プログラムから制御 するための関数ライブラリーの開発である．GPUの場合 には，その本来の目的である 3 次元グラフィックス処理の ために，OpenGLなどの優れたライブラリーがすでに開発 され，無償で提供されている。これらを利用すれば， $\mathrm{C}++$ などの高水準なプログラミング言語から，GPUのさまざ まな機能にアクセスし処理を行わせ，その結果を取得する ことができる.

\section{3. 逆オフセット法のハードウェア処理}

3 次元 $\mathrm{CG}$ の技術を用いて CAM 計算を高速化する典型 的な例として，GPUを利用した逆オフセット法のハード ウェア处理を紹介する．3軸の NC 切削加工において，工 具が製品（例之ば金型）へ削り込むガウジ問題を解決する には，製品を工具の逆形状分膨らませた形状を，あらかじ め生成しておけばよい. 工具経路を生成する際に，常にこ の膨張形状の上側を工具中心が通過するように注意すれ ば，ガウジを完全に回避できる．この膨張形状の上側の面 を，以後「工具経路面」と呼ぶことにする。

\section{1 逆オフセット法による工具経路面の算出}

製品形状を精密に多面体化したモデルが与えられている ものとする．ボールエンドミルを用いて切削加工する場 合, この多面体形状に対応する工具経路面は, 多面体の頂 点, 辺, ポリゴンを, 工具と等しい半径の球面, 円筒形, 板形状に置き換えたときの，これらの和形状の最上面とな る(図 2 参照)。逆オフセット法はこの最上面を以下の手 順で離散的に計算する ${ }^{2)}$.

最初に基準となる直交座標系をその $z$ 軸がボールエンド ミルの回転軸の上向き方向と一致するように与え，その $x y$ 平面上に $x$ 軸と $y$ 軸に平行から等間隔な直交格子を生成す る. 次に各格子について, その中心を通過する $z$ 軸に平行 な直線とすべての球面，円筒形，板形状の交差を調へ，最 も上側の交点，すなわち $z$ 座標值が最大の交点を選択する

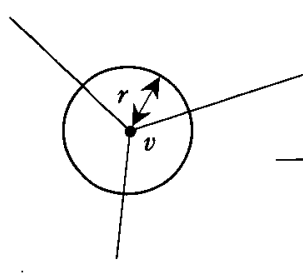

(a)

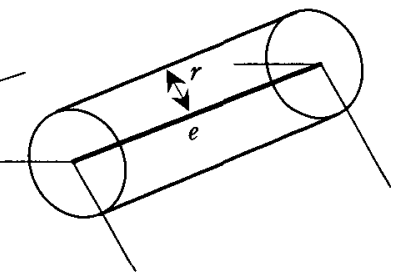

(b)

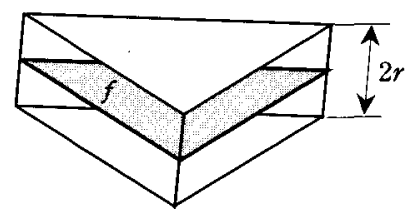

(c)

図 2 頂点 $v$, 辺 $e$, ポリゴン $f に$ 与えられた球面, 円筒形, 板形状

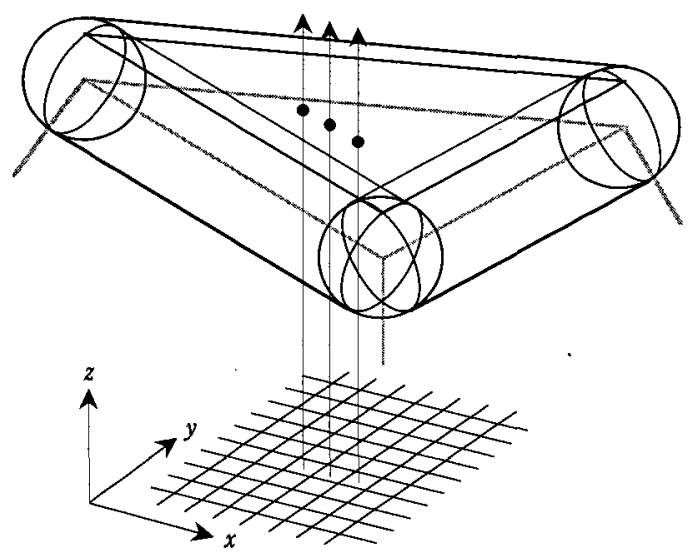

図 3 各格子から伸びる垂直線と球面, 円筒形, 板形状の交点のサ ンプリング

(図 3 参照).この処理を全格子について繰り返すと, 工 具経路面を覆う稠密な点群を得ることができる，そこでこ れらの点を適切に多面体化し, 工具経路面として出力す る.

\section{2 鿵面消去処理への置き換え}

逆オフセット法は, 3 次元 CGにおいて, 他の面に隠さ れて観察者から見えない「隐面」を消去した画像を生成す るために用いられる，デプスバッファ法に置き換えること ができる゙．图4のように配置された立方体を観察した画 像を，平行投影に上り描画することを考える.フレームバ ッファ上に, 処理の基準となる座標系を，その $z$ 軸の方向 が観察者の視線方向の逆を向くように, また $x$ 軸と $y$ 軸が フレームバッファのピクセルの格子と平行になるように与 える. また各ピクセルと 1 対 1 に対応する要素からなるデ プスバッファと呼ばれる配列を用意し，その各要素に初期 值として十分に小さな数值を与えておく.

準借の後，立方体を構成するポリゴンを，平行投影によ 


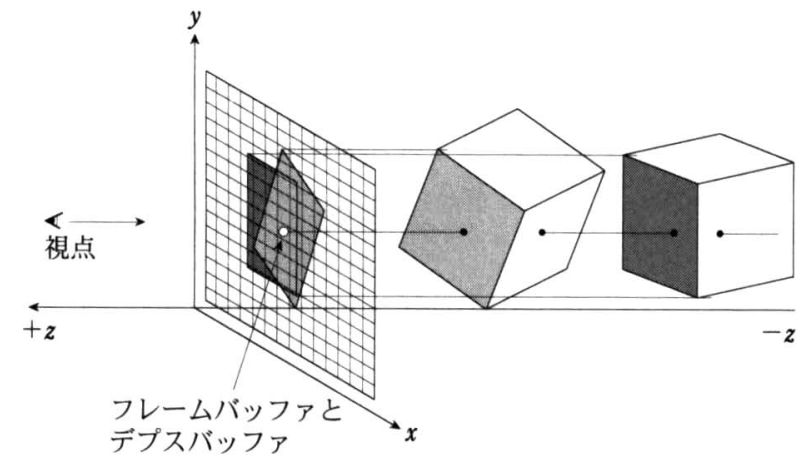

図4 デプスバッファ法による隠面の消去

り順にフレームバッファへ描画していく。その際にGPU は, 各ピクセルへ投影される多角形上の点の $z$ 座標值を計 算し, ピクセルに対応するデプスバッファ要素の值（これ をデプス值とよぶ) と比較する.もしも $z$ 座標值がデプス 值よりも大きいときには, ピクセルを点の色で染め, その $z$ 座標值を新しいデプス值として記録する.この処理をす べてのポリゴンについて繰り返すと, 各ピクセルには最も 手前側のポリゴンの色が染められることになり, 結果とし て隠面を消去した画像がフレームバッファに描かれる。そ のときデプスバッファには, 各ピクセルに対応する立体上 の点の $z$ 座標值が格納されている.

観察者の視線方向を工具回転軸の下向き方向に定め, 画 面のピクセル群を $x y$ 平面上の直交格子と対応づけると ;

（1）すべての格子について，その中心を通過する $z$ 軸に 平行な直線と, 多面体上に配置された球面, 円筒 面, 板形状の最も上側の交点を計算すること.

（2）すべての球面，円筒形，板形状を平行投影し，デプ スバッファを用いて, これらの隐面を消去した画像 を,フレームバッファに描くこと.

は, 幾何的に等価な処理になる. 全球面, 円筒形, 板形状 を描き終えたとき，デプスバッファの各要素には対応する 直線と球面, 円筒形, 板形状群との最も上側の交点の $z$ 座 標值が格納されているので, 工具経路面を表す点群を容易 に得ることができる.

\section{3 計算例}

上述の手法に基づいて, 従来技術と比較して数十倍以上 高速な逆オフセット法のプログラムを実装した。この手法 では, 逆オフセット法の計算の基本となる格子のサイズ は, フレームバッファのピクセル数の制約を受けるが，ピ クセル数よりも大きなサイズの格子が必要な場合には, 製 品形状を幾つかの部分に分割し, 各部分形状について工具 経路面を GPU を用いて計算し, 後からそれらをはり合わ せればよい. 図 5 には, 自動車のフロントフェンダー部 の成型用金型を，本技術に基づいて生成された走査線状の 工具経路を用いて荒加工（ している様子を示す。この例では格子の間隔は $10 \mu \mathrm{m}$ に 設定してある. 従来の CAM プログラムでは，膨大な計算

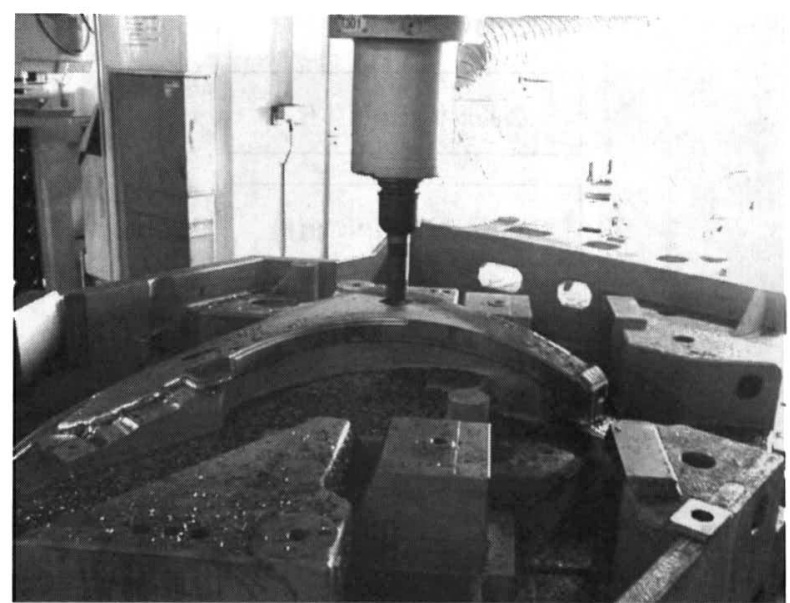

図 5 高速な逆オフセット法により計算された経路を用いた荒加工 (写真提供 マッダ (株))
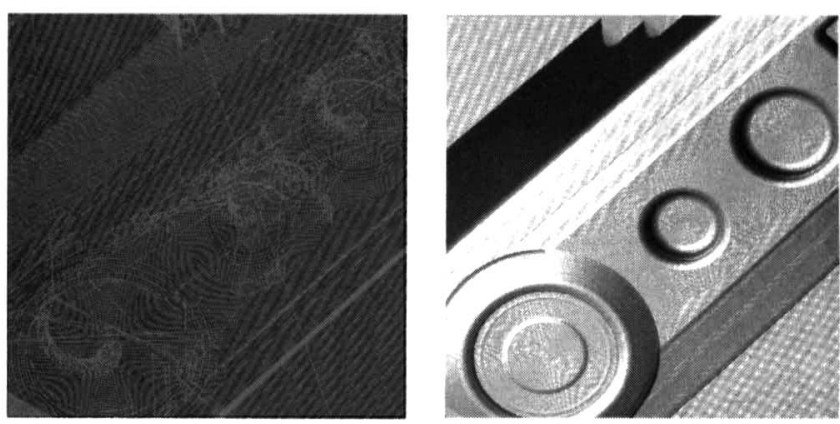

図 6 高速かつ高品質な加工シミュレーションの結果

時間が問題となっていたが，本技術を用いると数分で経路 計算を終えることができる.

\section{4. その他の CAM プログラムの高速化}

$\mathrm{CG}$ 技術を利用することで，逆オフセット法以外にもさ まざまな CAM 処理を高速化できる，以下にそのあらまし を示す.

加エシミュレーション：NC 切削加工の幾何的なシミュ レーションは, 移動する工具の掃引形状を工作物の立体モ デルから差し引くことで実現できる。この処理は，上述し た逆オフセット法とよく似ており，ほほ同じ手順で GPU によるハードウェア処理が可能である゙. プレス加工では, 工具経路デー夕はしばしば数百万ブロックとなるが, 本技 術を用いると加工結果を数十秒で得ることができる（図 6 参照).

削り残し形状の判定 : 金型加工では, 大半径の工具で取 り残した部分を，より径の小さな工具を用いて除去する作 業を繰り返す。逆オフセット法による経路生成と, 加工シ ミュレーションを繰り返し適用すると，この削り残し部を 高速に可視化でき，次に用いるべき工具の選択や，工具経 路を生成すべき領域を自動決定できる.

ポケット加工のための経路生成：ポケット形状の内部を 
周回しつつ削りつくす工具経路は，ポケットの輪郭形状の ボロノイ図を用いることで，高速に計算できる。このボロ ノイ図の画像は，3次元 $\mathrm{CG}$ の技術を用いて生成可能であ る.われわれは得られた画像からボロノイ頂点や辺の構造 を抽出し，その情報に基ついて周回する工具経路を高速か つ安定に計算する手法を実現した。

上述した技術のほかにも，5軸加工のシミュレーショ ン, 加エアニメーションの高速化占など, さまざまな研究 や開発が企業や大学で進められている. 逆オフセット法に ついては, 処理の高速化と並行して, 精度や形状品質を改 善する研究も進行しており, 縦壁部の形状が荒れる, 精度 を上げようとすると膨大な量のメモリーを要す，などの問 題点も解決しはじめている ${ }^{6}$.

\section{5. まとめと展望}

本稿では，ポリゴン表現と GPU の利用によるCAM 処 理の高速化技術について述べた。この技術はほかにも以下 に示すような優れた特徵を借えており，CAMのための新 しいプログラム開発手法として，定着の兆しを見せはじめ ている.

簡素なプログラム：本手法では，逆オフセット法におけ る最も上側の交点の取得などの面倒な計算は, すべて GPU によりハードウェア処理される．そのためプログラムが非 常に簡素なものになる.

安定な計算：図形処理では，計算梹差により幾何的な判 定結果に矛盾を生じ，処理が破綻することが問題になって いる. 本手法では, 必要な計算はポリゴンの描画だけなの で,この種の矛盾が発生しにくい.

ハードウェアの進歩：GPUの性能向上は著しいので, 多面体描画用のボードを最新のものへ交換すれば，それだ けで 2 4 倍の性能向上を達成できる.この種のボードは 廉価で販売されているため，交換コストはごくわずかであ る.

一方で実用化に際しては, 次のような問題の指摘もあ る。

多面体化の品質：CG 技術に基づく $\mathrm{CAM}$ では，加工結 果は多面体化された製品形状の「品質」に大きな影響を受 ける. ポリゴンのわずかな折れ曲がりが, 加工面の品質低
下につながる．曲面形状の多面体化については多くの研究 成果があるが，そのほとんどはデイスプレイ表示を目的と している．CAMでの利用に耐える，高品質な手法が望ま れている.

ハードウェアの特性：OpenGLなどの標準的なライブラ リーを用いて実装しても，GPUによって CAMの処理結 果に微妙な違いを生じることがある。この傾向は，超高性 能を狙った GPUほど著しい．実用にあたっては，GPUを よく吟味し, 最適な結果が得られるものを選択する必要が ある。

3 次元 CG 技術の利用により, 工具経路の生成や加工シ ミュレーションに要する時間が従来の数十分の 1 にまで短 縮された結果，これまでバッチ的に行うことが普通だった CAM 処理を，対話的に行うことが可能になってきた．先 行している企業では, 経路生成とシミュレーションを短時 間に繰り返し実行し，経路の品質をさらに高める工夫をし ている.

加工準備に要する時間が短縮されれば，その前段階の型 設計や製品設計に振り向けられる時間が增え, 結果として 製品品質がさらに改善されることになる．技能のデジタル 化に関する研究がさまざまなところで進められているが， CAM 処理などでの無駄な待ち時間を徹底的に压縮し，技 能者がその力を最大限発揮できる情報処理環境を整備する ことこそが，日本の製造業の競争力アップに重要と考えて いる.

\section{参 考 文 献}

1) T.Saito and T.Takahashi: NC Machining with G-Buffer Method, Computer Graphics, 25, 4, (1991) 207.

2）近藤 司，岸浪建史，斎藤勝政：逆オフセット法をもとにし た形状加工，精密工学会誌，54，5（1988）971.

3）乾 正知, 垣尾良輔：NC加工命命の高速な生成手法一逆オフ セット法のハードウェアによる高速化一, 精密工学会誌, 66, 12 (2000) 1901.

4) 乾 正知, 垣尾良輔: NC 加工結果の高速な可視化手法 -3 次 元グラフィックス表示装置の利用 - , 精密工学会誌, 65,10 (1999) 1466.

5）乾 正知，高野誠人：部分的な再描画による NC 加工プロセス の高速なアニメーション, 情報処理学会論文誌, 42,3 (2001) 478.

6）乾 正知, 崔 原己： NC 加工命令の高速な生成手法一逆オフ セット法の高精度化一, 精密工学会誌, 68, 10 (2002) 1316. 